\title{
Synthesis and properties of an unexpected trinuclear copper(I) complex supported by diphenylphosphinomethane
}

\author{
Ling-Zhi Tang ${ }^{a}$, Chen-Neng Lin ${ }^{a}$, Shu-Zhong Zhan ${ }^{a *}$, Xiao-Hua Xie ${ }^{{ }^{*} *}$ \\ ${ }^{a}$ College of Chemistry \& Chemical Engineering, South China University of \\ Technology, Guangzhou 510640, China \\ ${ }^{b}$ College of Chinese Language and Culture of Jinan University, 510610 Guangzhou,
}

China

\begin{abstract}
The reaction of $\mathrm{CuCl}_{2} \cdot 2 \mathrm{H}_{2} \mathrm{O}$, diphenylphosphinomethane (dppm), and tetracyanoethylene (TCNE) affords one unexpected trinuclear copper(I) complex, $\left[\mathrm{Cu}_{3}^{\mathrm{I}}(\mathrm{dppm})_{3}\left(\mu_{3}-\mathrm{Cl}\right)_{2}\right] \cdot[\mathrm{TCMA}] \mathbf{1}$ (TCMA: tricyanoacrylmethylate, a new compound deriving from TCNE). Structural study shows that three copper atoms are connected by dppm ligands bridging each edge to form a $\mathrm{Cu}_{3} \mathrm{P}_{6}$ unit. At room temperature, $\mathbf{1}$ appears photoluminescence at $447 \mathrm{~nm}$. And 1 also can electrocatalyze hydrogen generation from acetic acid with a turnover frequency (TOF) of 99.9 moles of $\mathrm{H}_{2}$ per mole of catalyst per hour at an overpotential of $941.6 \mathrm{mV}$.
\end{abstract}

Keywords: Copper(I) complex; crystal structure; photoluminescence; proton reduction; hydrogen generation

\footnotetext{
* Corresponding author. Fax: +86-20-87112053.

E-mail address: shzhzhan@scut.edu.cn (S.-Z. Zhan).
} 
Researchers often focus their interests on tetracyanoethylene (TCNE) chemistry, because TCNE is one of the most versatile organic compounds as it is used in many different reactions [1-4]. It has been shown that TCNE has the ability to accept one or two electrons to form anions and to bond with metal ions. And several molecular magnetic materials have been provided by reactions of TCNE with paramagnetic metal ions [5-9]. Despite these advances, few materials based on copper complexes supported by TCNE are known. To meet this need, we have tried the reaction of TCNE, $\mathrm{CuCl}_{2} \cdot 2 \mathrm{H}_{2} \mathrm{O}$ and dppm with a molar ratio set of $1: 1: 1$, surprisingly, an unexpected product $\left[\mathrm{Cu}_{3}^{\mathrm{I}}(\mathrm{dppm})_{3}\left(\mu_{3}-\mathrm{Cl}\right)_{2}\right] \cdot[\mathrm{TCMA}] \mathbf{1}$ was obtained. In this paper, we describe synthesis, structure and properties of complex $\mathbf{1}$, as well as its electrocatalytic hydrogen generation from acetic acid.

Generally, the reactions of TCNE (linker) with transition metal compounds afford polymers bridged by TCNE. However, the reaction of TCNE, $\mathrm{CuCl}_{2} \cdot 2 \mathrm{H}_{2} \mathrm{O}$ and dppm provides an unexpected trinuclear copper(I) complex 1 (Scheme 1), which can't be obtained by the reaction of TCNE, $\mathrm{CuCl}$ and dppm [10]. It is noteworthy that the copper oxidation state of $\mathbf{1}$ is +1 . During the course of the synthesis of complex $\mathbf{1}$ outlined above, probably, TCNE facilitates the reduction of the copper(II) to copper(I). The more detailed mechanistic studies are under investigation. Meanwhile, the above reaction also affords a tricyanoacrylmethylate ion, TCMA: Based on the literature precedent $[3,11,12]$, a possible mechanism for the formation of $\mathrm{TCMA}^{-}$is illustrated by Scheme 2. TCNE reacts with water in basic condition to form pentacyanopropenide, $\left[\mathrm{C}_{3}(\mathrm{CN})_{5}\right]^{-}$. Then, the addition of $\mathrm{O}_{2}$ provides an active species, 
A. Furthermore, A reacts with $\mathrm{CH}_{3} \mathrm{OH}$ to give TCMA- This is consistent with that TCNE undergoes numerous reactions [13]. From Fig. S1, the infrared spectrum of $\mathbf{1}$ shows two $v(\mathrm{C} \equiv \mathrm{N})$ stretches at 2199 , and $2169 \mathrm{~cm}^{-1}$ at lower energy than that of the free tetracyanoethylene (2215 and $2258 \mathrm{~cm}^{-1}$ ) (Fig. S2), assigning to two different cyanide modes of $\mathbf{1}$. From Fig. S3, complex 1 exhibits a high-energy absorption band at about $267 \mathrm{~nm}$, which is assigned to intraligand transitions.

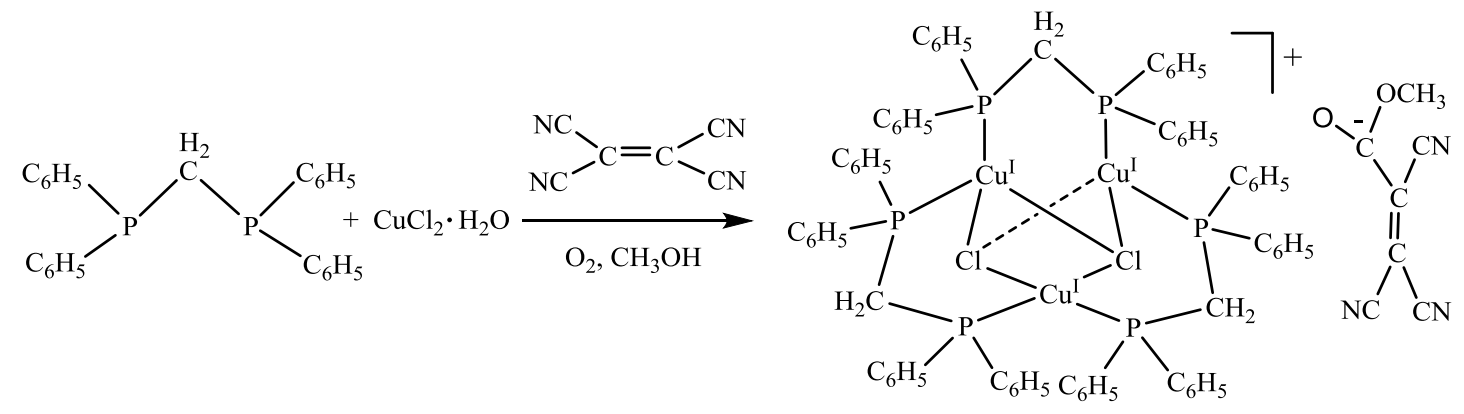

Scheme 1 Synthesis of complex 1.
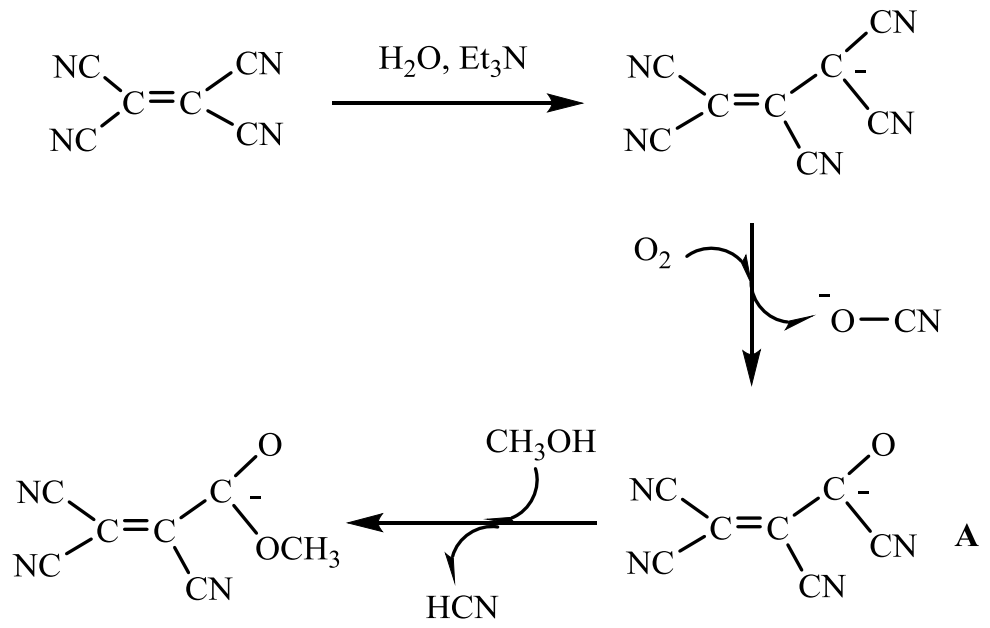

Scheme 2 The procedure for the formation of $\mathrm{TCMA}^{-}$anion.

Complex 1 crystallizes in space group P-1, with two formula units present per unit cell, and consists of one trinuclear copper(I) $\left[\mathrm{Cu}_{3}^{\mathrm{I}}(\mathrm{dppm})_{3}\left(\mu_{3}-\mathrm{Cl}\right)_{2}\right]^{+}$unit, and one TCMA $^{-}$anion. As shown in Fig. 1, three copper atoms are connected by dppm ligands 
to form a $\mathrm{Cu}_{3} \mathrm{P}_{6}$ unit. Each copper atom is coordinated by two chloride ions and two phosphorus atoms of dppm. Both chloride ions are bonded to the three copper atoms in a $\mu_{3}$ fashion from opposite faces of the triangle. The $\mathrm{Cu}_{2} \mathrm{P}_{2} \mathrm{C}$ rings adopt envelope conformations with the methylene carbon atoms on the flap, one of them folded toward one of the faces, and the other two away from it. The two phenyl rings attached to a phosphorus center stay on opposite sides of the plane formed by the three copper centers. The $\mathrm{Cu}-\mathrm{P}$ bond lengths vary over a small range of 2.2331(3)-2.2649(3) $\AA$. Cl(6) binds the copper atoms with one short (2.4007(3) $\AA$ ) and two long (2.4855(3) and 2.4925(4) $\AA$ ) bonds, whereas $\mathrm{Cl}(11)$ binds the copper

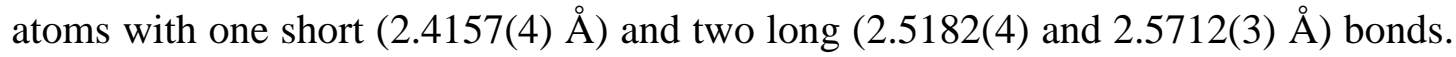
Note, in DMF, 1 exhibits the same form as that in solid, which is in agreement with the result from ESI-MS measurement which exhibits one ion at a mass-to-charge ratio $(\mathrm{m} / \mathrm{z})$ of 1413.0886 , with the mass and isotope distribution pattern corresponding to that of $\left[\mathrm{Cu}_{3}(\mathrm{dppm})_{3}(\mathrm{Cl})_{2}\right]^{+}$(Fig. S4), indicating that this complex is stable in solution. It has been shown that many $\mathrm{d}^{10}$ metal complexes display fascinating luminescent properties [14], therefore, we measured the emission spectrum of complex 1 in DMF at room temperature. As shown in Fig. 2, irradiation of complex 1 around $355 \mathrm{~nm}$ gives a strong emission at $447 \mathrm{~nm}$, which are found in other copper(I) complexes [15-18].

Fig. 2. Emission spectra of complex 1 and blank in DMF.

To explore if this copper(I) complex can act as an electrocatalyst, the 
electrochemical measurements for complex 1 were conducted in DMF solution with $0.10 \mathrm{M}\left[(\mathrm{n}-\mathrm{Bu})_{4} \mathrm{~N}\right] \mathrm{ClO}_{4}$ as the supporting electrolyte. Fig. 3 represents the $\mathrm{CV}$ of complex 1 in DMF, and a quasi-reversible redox couple is found in the potential of $-0.82 \mathrm{~V}$ versus $\mathrm{Ag} / \mathrm{AgNO}_{3}$, which can be assigned to that of $\mathrm{Cu}^{\mathrm{I}} / \mathrm{Cu}^{0}$.

Fig. 3. Cyclic voltammogram of $1.78 \mu \mathrm{M}$ complex 1 in DMF. Conditions: room temperature, $0.10 \mathrm{M}\left[\mathrm{n}-\mathrm{Bu}_{4} \mathrm{~N}\right] \mathrm{ClO}_{4}$ as supporting electrolyte, scan rate: $100 \mathrm{mV} / \mathrm{s}$, glassy carbon working electrode ( $1 \mathrm{~mm}$ diameter), $\mathrm{Pt}$ counter electrode, $\mathrm{Ag} / \mathrm{AgNO} \mathrm{H}_{3}$ reference electrode. Ferrocene internal standard (*).

From Fig. 4 it can be seen that the catalytic currents near $-0.86 \mathrm{~V}$ versus $\mathrm{Ag} / \mathrm{AgNO}_{3}$ increase with increasing proton concentration (acetic acid concentration increased from 0.0 to $2.68 \mathrm{mM}$ ). This indicates that hydrogen evolution electrocatalyzed by 1 requires the reduction of $\mathrm{Cu}(\mathrm{I})$ to $\mathrm{Cu}(0)$ and protonation. Interestingly, with the acetic acid concentration increases from 0.0 to $2.68 \mathrm{mM}$ (Fig. 4), the potential of $\mathrm{Cu}^{\mathrm{I}} / \mathrm{Cu}^{0}$ moves positive about $60 \mathrm{mV}$ from $-0.88 \mathrm{~V}$ to $-0.82 \mathrm{~V}$, and the onset of the catalytic wave also moves positive about $430 \mathrm{mV}$ compared to that in the absence of $\mathbf{1}$.

Fig. 4. CVs of a $1.78 \mu \mathrm{M}$ solution of complex $\mathbf{1}$, with varying concentration of acetic acid in DMF. Conditions: $0.10 \mathrm{M}\left[\mathrm{n}-\mathrm{Bu}_{4} \mathrm{~N}\right] \mathrm{ClO}_{4}$ as supporting electrolyte, scan rate: $100 \mathrm{mV} / \mathrm{s}$, glassy carbon working electrode (1 mm diameter), Pt counter electrode, $\mathrm{Ag} / \mathrm{AgNO}_{3}$ reference electrode, Fc internal standard (*). 
To further testify the catalytic activities of this copper(I) complex, bulk electrolysis was conducted in DMF with acetic acid at variable applied potential using a glassy carbon plate electrode in a double-compartment cell. Fig. 5a shows the total charges of bulk electrolysis from complex 1 in the presence of acid, and the charge significantly increased when the applied potential was set to more negative. When the applied potential was $-1.45 \mathrm{~V}$ versus $\mathrm{Ag} / \mathrm{AgNO}_{3}$, the maximum charge reached $45 \mathrm{mC}$ during 2 min of electrolysis, with accompanying evolution of a gas, which was confirmed as $\mathrm{H}_{2}$ by gas chromatography. According to Fig. S5, $\sim 0.73 \mu \mathrm{L}$ of $\mathrm{H}_{2}$ was produced over an electrolysis period of $2 \mathrm{~h}$ under $-1.45 \mathrm{~V}$ versus $\mathrm{Ag} / \mathrm{AgNO}_{3}$. And a controlled-potential electrolysis (CPE) experiment under the same potential without $\mathbf{1}$ gave a charge of only $8 \mathrm{mC}$ (Fig. 5b), showing that this copper complex does indeed serve as effective hydrogen producer under such conditions. From Equations (1) [19] and (2) [20], the TOF was estimated to be 99.9 moles of hydrogen per mole of catalyst per hour (Eq. S1 and Fig. S6), which is higher than a dinuclear copper(I) supported by 1-[(2-methoxy) benzene]-3-[2-(chloro)benzene] triazene ion that shows a TOF of 65 moles of $\mathrm{H}_{2}$ per mole of catalyst per hour at an overpotential of 941.6 $\mathrm{mV}$ [21], yet smaller than a trinuclear copper(I) with triazenido ligands that exhibits a TOF of 136 moles of $\mathrm{H}_{2}$ per mole of catalyst per hour at an overpotential of $688 \mathrm{mV}$ [22].

$\mathrm{TOF}=\Delta C /\left(\mathrm{F}^{*} n_{1} * n_{2}^{*} t\right)$

Overpotential $=$ Applied potential $-\mathrm{E}^{\odot} \mathrm{HA}$

$$
=\text { Applied potential }-\left(\mathrm{E}^{\odot}{ }_{\mathrm{H}}^{+}-(2.303 R T / F) \mathrm{p} K_{a \mathrm{HA}}\right)
$$


Where, $\Delta C$ is the charge from the catalyst solution during CPE minus the charge from solution without catalyst during CPE; $\mathrm{F}$ is Faraday's constant, $n_{1}$ is the number of moles of electrons required to generate one mole of $\mathrm{H}_{2}, n_{2}$ is the number of moles of catalyst in solution, and $\mathrm{t}$ is the duration of electrolysis.

Fig. 5. (a) Charge buildup versus time from electrolysis of a $0.071 \mu \mathrm{M}$ complex 1 in $\operatorname{DMF}\left(0.10 \mathrm{M}\left[\mathrm{n}-\mathrm{Bu}_{4} \mathrm{~N}\right] \mathrm{ClO}_{4}\right)$ under various applied potentials. All data have been deducted blank. (b) Charge buildup versus time from electrolysis of a $0.10 \mathrm{M}$ $\left[\mathrm{n}-\mathrm{Bu}_{4} \mathrm{~N}\right] \mathrm{ClO}_{4}$ solution in DMF under $-1.45 \mathrm{~V}$ versus $\mathrm{Ag} / \mathrm{AgNO}_{3}$.

We used UV-vis spectra to examine the stability of complex 1 by employing an optically semi-transparent thin layer electrode. As shown in Fig. S7, the intensity of the absorption band at $267 \mathrm{~nm}$ slightly increases during $3 \mathrm{~h}$ electrolysis, but the peak position does not change, indicating $\mathbf{1}$ is stable under these conditions.

\section{Summary}

$\mathrm{CuCl}_{2} \cdot 2 \mathrm{H}_{2} \mathrm{O}$ reacts with dppm, and TCNE to produce one unexpected trinuclear copper(I) complex $\quad\left[\mathrm{Cu}_{3}^{\mathrm{I}}(\mathrm{dppm})_{3}\left(\mu_{3}-\mathrm{Cl}\right)_{2}\right] \cdot[\mathrm{TCMA}] \mathbf{1}$, which can't be obtained by the reaction of $\mathrm{CuCl}$, dppm, and TCNE. Complex 1 exhibits photoluminescence behavior at room temperature. And $\mathbf{1}$ also can electrocatalyze hydrogen generation from acetic acid.

\section{Acknowledgements}

This work was supported by the National Science Foundation of China (No. 20971045 and 21271073). 


\section{References}

[1] W. Kaim, M. Moscherosch. The coordination chemistry of TCNE, TCNQ and related polynitrile $\pi$ acceptors. Coord. Chem. Rev. 129 (1994) 157-193.

[2] A. Aumuller, P. Erk, S. Hunig. A new class of compounds with high electrical conductivity molecular crystals and liquid crystals. Mol. Cryst. Liq. Cryst. 156 (1988) $215-221$.

[3] J. S. Miller. Tetracyanoethylene (TCNE): The characteristic geometries and vibrational absorptions of its numerous structures. Angew. Chem. Int. Ed. 45 (2006) 2508-2525.

[4] J. D. Bagnato, W. W. Shum, M. Strohmeier, D. M. Grant, A. M. Arif, J. S. Miller. The structure of fractionally charged tetracyanobenzene ${ }^{n-}$ present in $[\mathrm{TCNB}]_{3}{ }^{2-}$. Angew. Chem. Int. Ed. 45 (2006) 5322-5326.

[5] G. Wang, H. Zhu, J. Fan, C. Slebodnick, G. T. Yee. Coordination complexes with cis-TCNE radical anion ligands. Models of $\mathrm{M}[\mathrm{TCNE}]_{2}$ magnets. Inorg. Chem. 45 (2006) 1406-1408.

[6] J. S. Miller, A. J. Epstein. Organic and organometallic molecular magnetic materials-designer magnets. Angew. Chem. Int. Ed. Engl. 33 (1994) 385-415.

[7] J. M. Manriquez, G. T. Yee, R. S. McLean, A. J. Epstein, J. S. Miller. A room-temperature molecular/organic-based magnet. Science 252 (1991) 1415-1417.

[8] G. T. Yee, J. M. Manriquez, D. A. Dixon, R. S. McLean, D. M. Groski, R. B. Flippen, K. S. Narayan, A. J. Epstein, J. S. Miller. Decamethylmanganocenium 
tetracyanoethenide, $\left[\mathrm{Mn}\left(\mathrm{C}_{5} \mathrm{Me}_{5}\right)_{2}\right]^{\odot \odot \oplus}[\mathrm{TCNE}]^{\odot} \ominus-\mathrm{a}$ molecular ferromagnet with an $8.8 \mathrm{~K} T_{c}$. Adv. Mater. 3 (1991) 309-311.

[9] J.-H. Her, P. W. Stephens, K. I. Pokhdnya, M. Bonner, J. S. Miller. Cross-linked layered structure of magnetically ordered $\left[\mathrm{Fe}(\mathrm{TCNE})_{2}\right] \cdot z \mathrm{CH}_{2} \mathrm{Cl}_{2}$ determined by rietveld refinement of synchrotron powder diffraction data, Angew. Chem. Int. Ed. 46 (2007) 1521-1524.

[10] Synthesis of $\left[\mathrm{Cu}_{3}(\mathrm{dppm})_{3}\left(\mu_{3}-\mathrm{Cl}\right)_{2}\right][T C M A] \mathbf{1}$

To a solution of $\mathrm{CuCl}_{2} \cdot 2 \mathrm{H}_{2} \mathrm{O}(0.171 \mathrm{~g}, 1 \mathrm{mmol})$ in methanol $(10 \mathrm{~mL})$ was added dppm (0.385 g, $1 \mathrm{mmol}$ ) in $30 \mathrm{~mL} \mathrm{CH}_{2} \mathrm{Cl}_{2}$, which leads to the formation of colorless solution after stirring for a period of $2 \mathrm{~h}$. To this solution was added TCNE ( $0.102 \mathrm{~g}, 1$ mmol) in $10 \mathrm{~mL} \mathrm{CH}_{2} \mathrm{Cl}_{2}$, and the mixture was stirred for another $60 \mathrm{~min}$. Single crystals were obtained from the filtrate which was allowed to stand at room temperature for several days, collected by filtration, and dried in vacuo $(0.31 \mathrm{~g}, 59 \%$ yield). Calcd for $\mathrm{C}_{82} \mathrm{H}_{69} \mathrm{Cu}_{3} \mathrm{Cl}_{2} \mathrm{~N}_{3} \mathrm{O}_{2} \mathrm{P}_{6}$ : C, 62.49; H, 4.36; N, 2.67. Found: $\mathrm{C}, 62.32 ; \mathrm{H}$, 4.33; N, 2.67. IR band $\left(\mathrm{KBr}\right.$ pellet, $\left.\mathrm{cm}^{-1}\right): v=2199,2169 v(\mathrm{C} \equiv \mathrm{N})$. Fluorescence spectrum: $\lambda_{\mathrm{ex}}=355 \mathrm{~nm}, \lambda_{\mathrm{em}}=447 \mathrm{~nm}$.

[11] C. Kremer, C. Melián, J. Torres, M. P. Juanico, C. Lamas, H. Pezaroglo, E. Manta, H. Schumann, J. Pickardt, F. Girgsdies, O. N. Ventura, F. Lloret, Synthesis, structure and magnetic properties of $\mathrm{Mn}(\mathrm{II})$ and $\mathrm{Cu}(\mathrm{II})$ complexes with the dicyano-acetic acid methyl ester anion. Inorg. Chim. Acta 314 (2001) 83-90.

[12] F. Conan, B. L. Gall, J.-M. Kerbaol, S. L. Stang, J. Sala-Pala, Y. L. Mest, J. Bacsa, X. Ouyang, K. R. Dunbar, C. F. Campana. Electrochemical, spectroscopic, and 
structural evidence for the mild hydrolysis of tetracyanoethylene, TCNE, to form the 2,3,3-tricyanoacrylamidate ligand: Isolation of an unexpected quadruply-bonded polymeric material $\left[\mathrm{Mo}_{2}\left(\mathrm{O}_{2} \mathrm{CCMe}_{3}\right)_{3}\left((\mathrm{NC})_{2} \mathrm{CC}(\mathrm{CN}) \mathrm{CONH}\right)\right]_{\infty}$. Inorg. Chem. 43 (2004) $3673-3681$.

[13] A. J. Fatiadi. New applications of tetracyanoethylene in organic chemistry. Synthesis (1986) 249-284.

[14] V. W.-W. Yam. Luminescent coinage metal clusters of acetylides and chalcogenides. J. Photochem. Photobio. A: Chem. 106 (1997) 75-84.

[15] G. Chakkaradhari, Y.-T. Chen, A. J. Karttunen, M. T. Dau, J. Jänis, S. P. Tunik, P.-T. Chou, M.-L. Ho, I. O. Koshevoy. Luminescent triphosphine cyanide $\mathrm{d}^{10}$ metal complexes. Inorg. Chem. 55 (2016) 2174-2184.

[16] G. Chakkaradhari, A. A. Belyaev, A. J. Karttunen, V. Sivchik, S. P. Tunik, I. O. Koshevoy. Alkynyl triphosphine copper complexes: synthesis and photophysical studies. Dalton Trans., 44 (2015) 13294-13304.

[17] H.-Y. Shi, Y.-L. Huang, J.-K. Sun, J.-J. Jiang, Z.-X. Luo, H.-T. Ling, C.-K. Lam, H.-Y. Chao. Assembly of $\mathrm{BF}_{4}^{-}, \mathrm{PF}_{6}^{-}, \mathrm{ClO}_{4}^{-}$and $\mathrm{F}^{-}$with trinuclear copper(I) acetylide complexes bearing amide groups: structural diversity, photophysics and anion binding properties. RSC Adv. 5 (2015) 89669-89681.

[18] G. Rajput, M. K. Yadav, M. G. B. Drew, N. Singh. Impact of ligand framework on the crystal structures and luminescent properties of $\mathrm{Cu}(\mathrm{I})$ and $\mathrm{Ag}(\mathrm{I})$ clusters and a coordination polymer derived from thiolate/iodide/dppm ligands. Inorg. Chem. 54 (2015) 2572-2579. 
[19] L. Tong, R. Zong, R. P. Thummel. Visible light-driven hydrogen evolution from water catalyzed by a molecular cobalt complex. J. Am. Chem. Soc. 136 (2014) $4881-4884$.

[20] G. A. N. Felton, R. S. Glass, D. L. Lichtenberger, D. H. Evans. Iron-only hydrogenase mimics. Thermodynamic aspects of the use of electrochemistry to evaluate catalytic efficiency for hydrogen generation. Inorg. Chem. 45 (2006) 9181 $-9184$.

[21] T. Fang, H.-X. Lu, J.-X. Zhao, S.-Z. Zhan, Q.-Y. Lv. A new copper(I)-triazenido electro-catalyst for catalyzing hydrogen evolution from acetic acid and water. J. Mol. Cata. A: Chem. 396 (2015) 304-309.

[22] T. Fang, L.-L. Zhou, L.-Z. Fu, S.-Z. Zhan, Q.-Y. Lv. Synthesis and studies of a molecular copper(I)-triazenido electrocatalyst for catalyzing hydrogen evolution from acetic acid and water. Polyhedron 85 (2015) 355-360. 

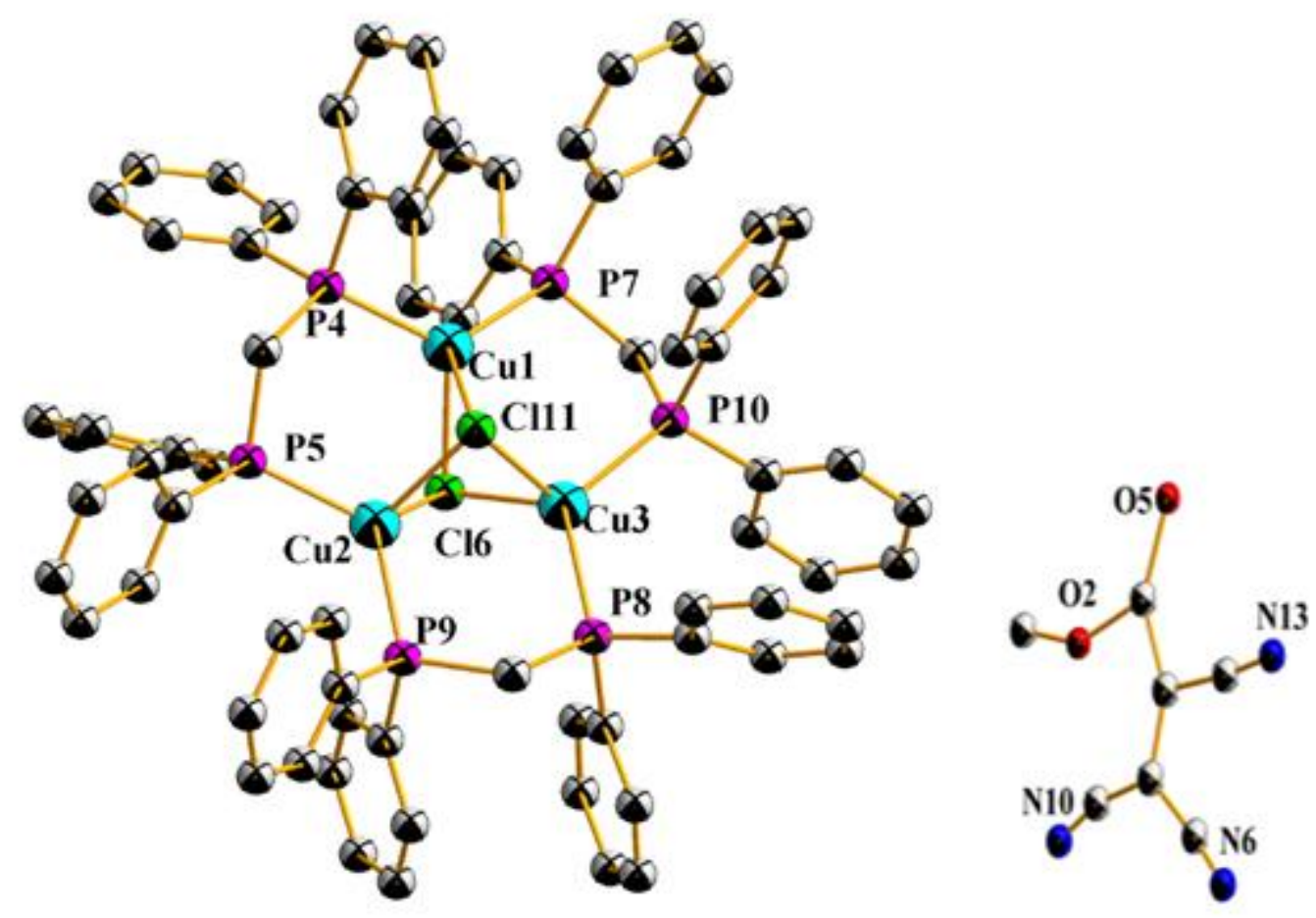

Fig. 1. ORTEP drawing of complex 1 with thermal ellipsoids on the $30 \%$ probability level (hydrogen atoms are not shown). 


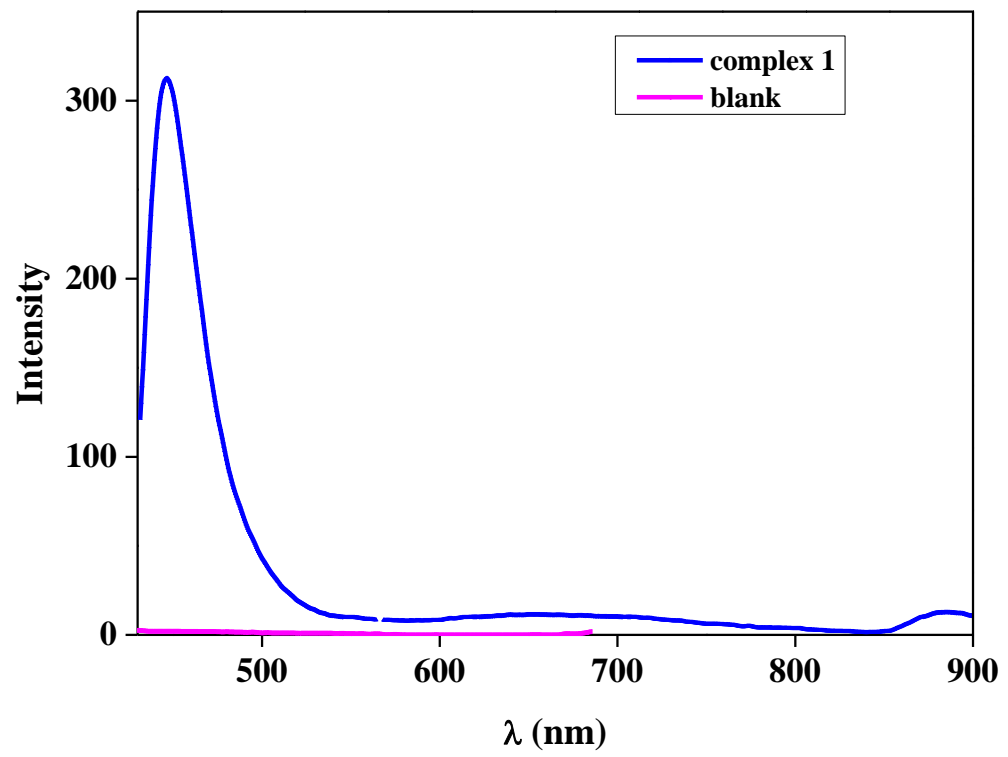

Fig. 2. Emission spectra of complex 1 and blank in DMF. 


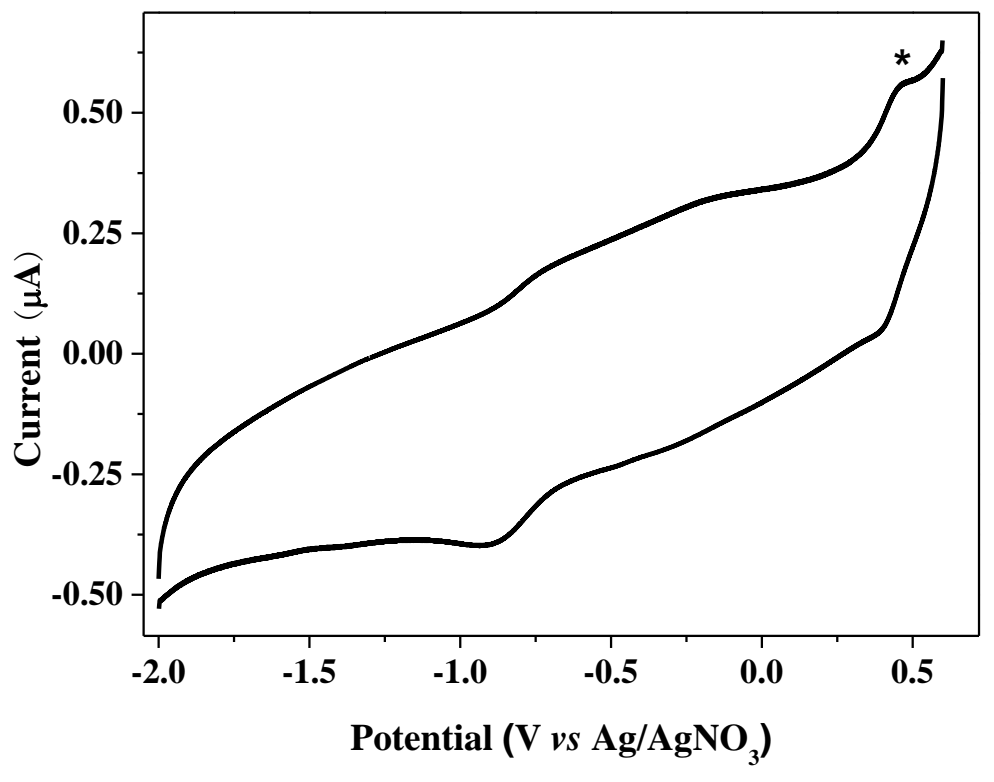

Fig. 3. Cyclic voltammogram (CV) of $1.78 \mu \mathrm{M}$ complex 1 in DMF. Conditions: 0.10 $\mathrm{M}\left[\mathrm{n}-\mathrm{Bu}_{4} \mathrm{~N}\right] \mathrm{ClO}_{4}$ as supporting electrolyte, scan rate: $100 \mathrm{mV} / \mathrm{s}$, glassy carbon working electrode (1 $\mathrm{mm}$ diameter), $\mathrm{Pt}$ counter electrode, $\mathrm{Ag} / \mathrm{AgNO}_{3}$ reference electrode. Ferrocene internal standard $(*)$. 


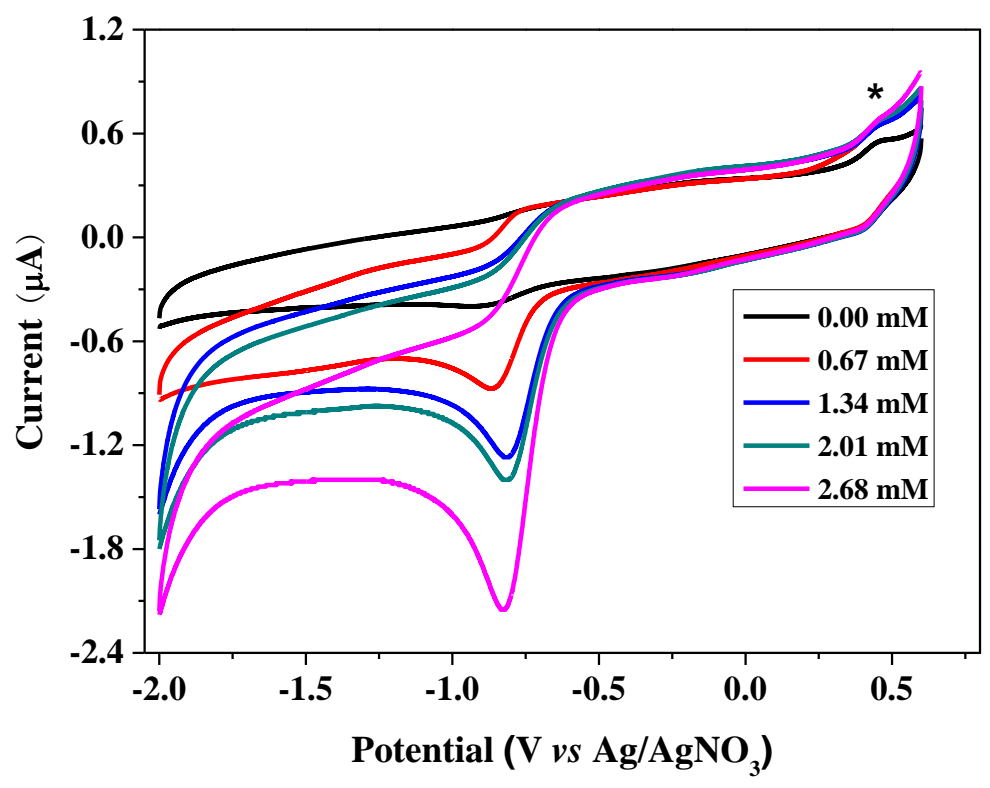

Fig. 4. CVs of a $1.78 \mu \mathrm{M}$ solution of complex $\mathbf{1}$, with varying concentration of acetic acid in DMF. Conditions: $0.10 \mathrm{M}\left[\mathrm{n}-\mathrm{Bu}_{4} \mathrm{~N}\right] \mathrm{ClO}_{4}$ as supporting electrolyte, scan rate: $100 \mathrm{mV} / \mathrm{s}$, glassy carbon working electrode (1 mm diameter), Pt counter electrode, $\mathrm{Ag} / \mathrm{AgNO}_{3}$ reference electrode, Fc internal standard (*). 

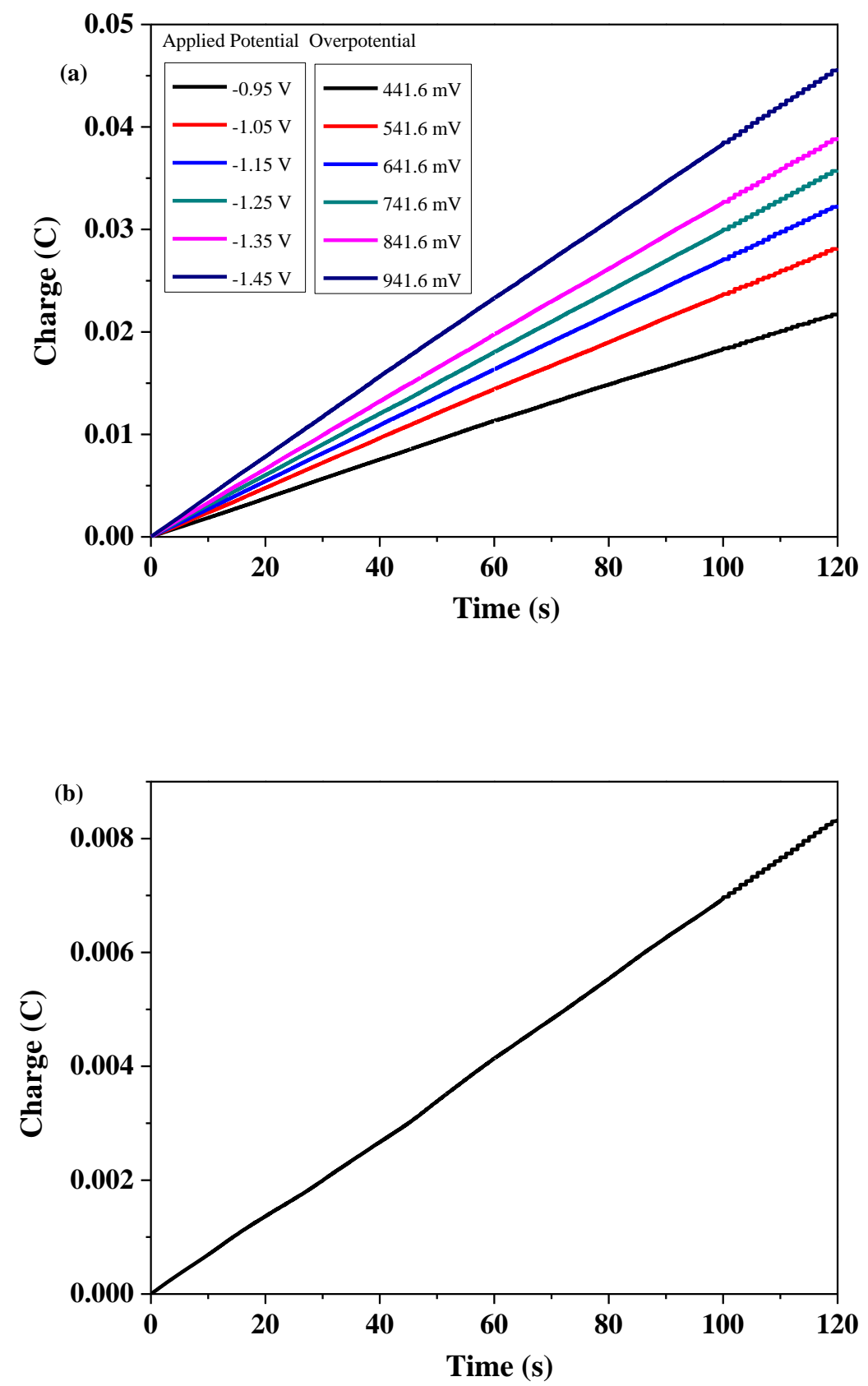

Fig. 5. (a) Charge buildup versus time from electrolysis of $0.071 \mu \mathrm{M}$ complex 1 in DMF $\left(0.10 \mathrm{M}\left[\mathrm{n}-\mathrm{Bu}_{4} \mathrm{~N}\right] \mathrm{ClO}_{4}\right)$ under various applied potentials. All data have been deducted blank. (b) Charge buildup versus time from electrolysis of a $0.10 \mathrm{M}$ $\left[\mathrm{n}-\mathrm{Bu}_{4} \mathrm{~N}\right] \mathrm{ClO}_{4}$ solution in DMF under $-1.45 \mathrm{~V}$ versus $\mathrm{Ag} / \mathrm{AgNO}_{3}$. 

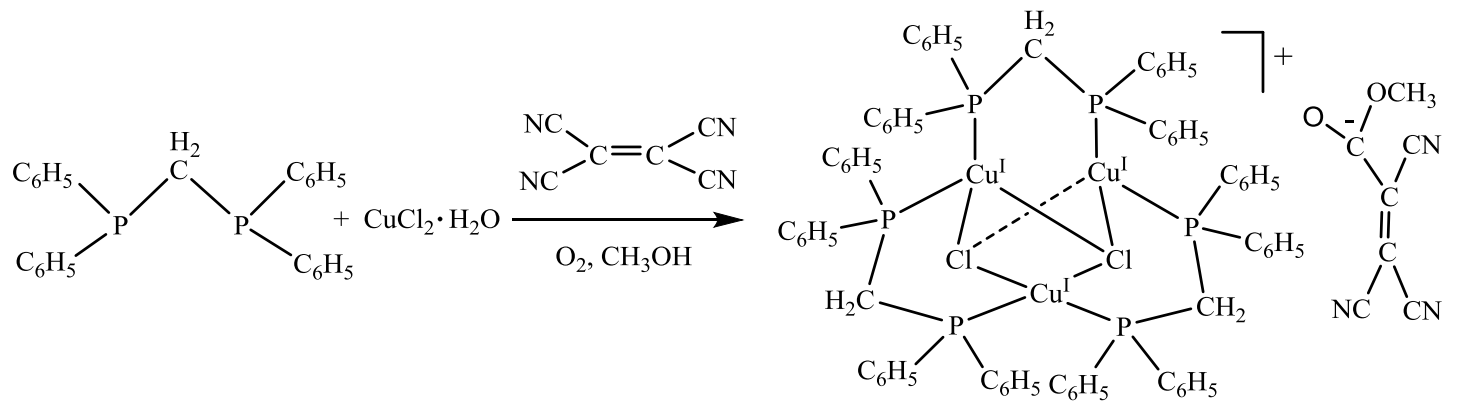
The reaction of tetracyanoethylene (TCNE), $\mathrm{CuCl}_{2} \cdot 2 \mathrm{H}_{2} \mathrm{O}$ and diphenylphosphinomethane (dppm) provides a trinuclear copper(I) complex $\left[\mathrm{Cu}_{3}^{\mathrm{I}}(\mathrm{dppm})_{3}\left(\mu_{3}-\mathrm{Cl}\right)_{2}\right] \cdot[\mathrm{TCMA}] \mathbf{1}$ (TCMA: tricyanoacrylmethylate). 